\title{
Value distribution and markets for social justice in global value chains: Interdependence relationships and government policy
}

\section{Lilac Nachum}

International Business Department, Baruch College, City University New York, 55 Lexington Avenue, New York, NY 10010-5585, USA.

Correspondence:

L Nachum, International Business

Department, Baruch College, City University New York, 55 Lexington Avenue, New York, NY 10010-5585, USA.

e-mail: lilac.nachum@baruch.cuny.edu
Received: 10 August 2019

Revised: 21 February 2021

Accepted: 23 February 2021

Online publication date: 19 March 2021

\begin{abstract}
Global value chains are highly prone to distortions in value distribution among participants. Their global fragmentation and relational governance undermine the effectiveness of regulatory intervention in amending these distortions. In this paper, I propose a new mechanism to administer value distribution that is in tune with the nature of these production systems. Building on interdependence theory, I suggest that interdependencies inherent in the cospecialized nature of supply chains give participants the power to alter the trade-offs between investment in social causes and economic gains and to incentivize socially desired behavior. I show how the interdependence logic manifests at varying levels of the GVC, including the producing constituencies, governments, and international organizations, as well as civil society. These dynamics create markets for social justice that are driven by relationships among GVC participants and operate simultaneously at different scales. I further posit that the effectiveness of interdependence relationships as a valuedistributing mechanism is socially-constructed and outline the social conditions that determine the outcomes. I specify the varying impact of governments on interdependence relationships - as activators, facilitators, or inhibitors of the transformative power of interdependencies - and discuss their effectiveness. Journal of International Business Policy (2021) 4, 54I-563. https://doi.org/ | 0.1057/s422 I 4-02 I-00 I05-w
\end{abstract}

Keywords: global value chains; government policy; social justice; value distribution; interdependence theory; power asymmetries

Nike and its retailers capture nearly $90 \%$ of the revenues of each shoe sold, whereas the combined revenues of the manufacturers of these shoes, which incur the cost of labor and material, amount for $12 \%$. The labor employed in the production receives $0.4 \%$ of the revenues (Rodrige, Comtois, \& Slack, 2013). Similar patterns are apparent across industries, including consumer electronics, iPhones and others (Dedrick, Kraemer, \& Linden, 2011; Kraemer, Linden, \& Dedrick, 2011). Such uneven value distribution is 
inconsistent with predictions of economic theory, according to which in equilibrium, economic actors generate rent from their participation in value creation that is proportional to the resources they invest (Lepak, Smith, \& Taylor, 2007; Medema, 2007; Pitelis, 2009). What then explains the uneven distribution of value among global value chain (GVC)'s participants? Why do neither market nor non-market forces impose value distribution that is aligned with value creation, in agreement with theoretical predictions? And in the failure of markets to distribute value adequately, why do governments not correct for these inequalities?

These questions are by no means new. Distortions of value distribution in GVCs and their consequences for economic development and social welfare have attracted enormous research attention for decades. Much of the GVC literature has sought means to reduce them and proposed a variety of government policies towards this end (Gereffi, 2018; Henderson et al., 2002; Kaplinsky, 2005; Milberg \& Winkler, 2013; Powell, 2014; World Bank, 2020). The stubborn persistence and proliferation of imbalanced value distribution in GVCs raise concerns regarding the effectiveness of these solutions (Bair \& Werner, 2011; Uramoto \& Nachum, 2018). Some studies show that not only do the anticipated gains of the policy recommendations not always materialize, they may lead to the opposite outcomes, locking participants in lowvalue added activities that undermine their ability to increase the share of value from their GVC participation (Humphrey \& Schmitz, 2002; Ponte, \& Gibbon, 2005; Rossi, 2013; Taglioni \& Winkler, 2016).

This state of affairs is troubling. GVCs have become the predominant organizational platform through which production is coordinated and organized on a global basis, accounting at the closing of the 2010 s for $80 \%$ of global trade and $60 \%$ of global production (Antras, 2020; World Bank, 2020). Some observers suggest that they have come to displace firms as the principal entity of value creation (Miles \& Snow, 2007). Inadequate value distribution of an organizational form of such significance is disturbing. It affects the well-being of millions of people around the world and undermines global value-creation potential (Bapuji, Ertug, \& Shaw, 2020).

In this paper, I seek to address this gap. I build on research on power in GVCs (Dallas, 2014; Dallas, Ponte, \& Sturgeon, 2019; Grabs \& Ponte, 2019;
Mahutga, 2014), and combine it with insights of interdependence theory (Coleman, 2011; Deutsch, 1949, 1973; Johanson \& Johanson, 2005), to develop a conceptualization of power that originates in interdependence relationships among GVC participants. I posit that interdependence relationships are a powerful mechanism for change because interdependencies are inherent in the very nature of value creation in GVCs (Gereffi, 2018), and their reciprocal nature is in tune with the combination of collaboration (in value creation) and competition (in value capture) that characterizes these production systems (Chatain \& Zemsky, 2011; Lepak et al., 2007; Tjosvold \& Wu, 2009). Conceptualizing interdependence relationships as a socially constructed concept that is subject to social legitimation (Coleman, Vallacher, \& Noward, 2011; Emerson, 1962; Kelly et al., 2003), I outline the transformative power of interdependence dynamics as the outcome of the social legitimation of the multiple societal contexts in which GVCs operate, and demonstrate its variation across societal settings and different GVC constellations. This conceptualization offers ground for distinguishing among four generic types of GVCs that vary by the effectiveness of the interdependence logic as a force for change and result in varying distributional outcomes. I show the varying role of government policy in each of these GVC types and suggest that the interdependence logic does not replace governments but rather assign them different roles.

With these conceptualizations, I advance discussions of value distribution in GVCs in several important ways. For one, the employment of the interdependence logic as a mechanism for change offers a novel approach for amending distributional distortions in GVCs. This approach is particularly suitable for a fragmented and diffused production system like the GVC that is scattered across different institutional settings with no hegemonic power to regulate them (Overdevest \& Zeitlin, 2014; Sabel $\&$ Zeitlin, 2010). Interdependence relationships derive their transformative power from dynamics inherent in the nature of GVCs, making them a powerful solution for correcting for distributional distortions, and substitute for a predominant authority in setting up the terms for operation and value distribution (Mayer \& Phillips, 2017; Schrank \& Whitford, 2011). Interdependencies create markets for social justice whereby economic incentives, originating in relationships internal to the GVCs, bring about change (Budish, Lee, \& Shim, 2019). Their transformative power originates 
in the very reasons for distributional distortions, namely power and interdependence asymmetries that are inherent in the nature of GVCs.

Further, by placing societal legitimation of the interdependence logic at the center of the discussion, I offer a framework for a systematic analysis of context, and contribute to extant research whose case-based, fragmented nature has often challenged such analyses. This framework enables me to delineate the contextual characteristics that permit the manifestation of the interdependence logic and define the boundaries of its transforming power. Absent these characteristics, interdependence relationships do not increase social welfare and may even be employed to undermine it. These contributions advance research about the complementarity between transnational and domestic efforts as the key for social change and just distributional outcomes (Amengual, 2010; Amengual \& Chirot, 2016; Bartley, 2011; Bruszt \& McDermott, 2014; Locke, 2013). The framework I introduce offers ground for expanding these discussions to multiple types of GVCs, including South-South and SouthNorth GVCs, which represent distinctive challenges for distributional outcomes. It also draws attention to constituencies that have gone unnoticed by extant research although they have considerable impact on value distribution, such as consumers and their consumption behavior.

Lastly, the framework I develop provides an overarching theoretical ground for identifying the diverse and nuanced role that governments play in activating, facilitating, or prohibiting the interdependence logics. It enables one to examine the varying consequences of government policy for value distribution in different types of GVCs. This analysis offers suggestive normative lessons regarding the adequate role for governments in amending distributional distortions in GVCs.

\section{ADDRESSING DISTORTIONS IN VALUE DISTRIBUTION IN GVCS: THE THEORETICAL BUILDING BLOCKS}

The framework I develop below derives its impetus from three principles that underlie value distribution in GVCs. Below I outline the theoretical underpinnings of each of them. ${ }^{1}$

\section{Goal: Economic Development Versus Value Distribution}

Discussions of value distribution in GVCs are typically geared towards understanding of the way by which countries can employ GVC participation as a mechanism towards economic and social development (Coe \& Young, 2015; Gereffi, 2018; Henderson et al., 2002; Schrank, 2004). Implicit in these discussions is the search for unilateral gains of individual countries and they result in policy recommendations that would serve this end. I posit that this approach is inconsistent with the contested nature of value distribution in GVCs whereby gains captured by each participant are dependent on impoverishment of others (Chatain \& Zemsky, 2011; Lepak et al., 2007; McGrath, 2018). Nor is it in tune with a global production system that transcends national borders and operates on multiple geographic scales, whereby the association of value to particular locations is obscured by global ambiguities (Baldwin, 2016; Mayer \& Gereffi, 2010). Such a system requires an approach that encompasses the system as a whole, and is attentive to the fact that amending distortions in one country may accentuate them in others (McGrath, 2018; Werner, 2019). The framework I develop below reflects on these principles and changes the focus from developmental and social goals of individual countries to a balanced distribution of value in the GVC as a whole. The GVC thus becomes the unit of analysis, and attention shifts to the dynamics that determine value distribution in the system as a whole rather than the economic development of individual nodes within it (Dicken, et al., 2001).

\section{Constituencies: Participants in the Negotiation for Value}

Discussions of the constituencies that negotiate for value in GVCs have focused predominantly on lead firms and their manufacturers as the major contenders for value and determinants of distributional outcomes (Gereffi, Humphry, \& Sturgeon, 2005). Recent attempts offered broader frameworks that view these participants within a broad societal context (Coe, Dicken, \& Hess, 2008; Gereffi, 2019) but the focus remained the dyad as the critical determinant of the outcome (Coe \& Young, 2015, 2019). In departure from this approach, I suggest that the structure of GVCs, whereby layers of activities are nested within each other with cross influences among them, requires a framework that recognizes relationships among multiple participants whose collective and simultaneous actions determine the distributional outcomes (Gereffi, 2019; Levy, 2008). To varying degrees, and in different ways, each of these constituencies has 
the power to influence the behavior of others, but the substance of their power, the means they possess to exploit it, and the geographic scale at which power manifests are different (Antras, 2020; Davis, Kaplinsky, \& Morris, 2018; McGrath, 2018; Werner, 2019). A unified framework that ties these multiple participants together mirrors the plurality of causes of distributional distortions and offers an appropriate lens through which to analyze the separate and collective influences of different constituencies and the linkages among them as they cut within and across GVC scales (Caschili, Medda, \& Wilson, 2015; Levy, 2008).

\section{Mechanisms: Sources of Power to Affect Value Distribution}

Explicitly or not, most GVC research has viewed power as the determinant of the economic gains and distributional outcomes of value chain participation (Dallas, 2014; Dallas et al., 2019; Davis et al., 2018). Research in this area has specified the analytical scope within which multiple power dimensions manifest and are exploited by different constituencies, whether in governance structure and GVC type (Gereffi et al., 2005; Grabs \& Ponte, 2019) or else in relational dynamics among participants (Coe \& Young, 2015; Henderson et al., 2002). I build on these conceptualizations and extend them by advancing a notion of power that originates in interdependence relationships (Deutsch, 1949, 1973; Johanson \& Johanson, 2005; Coleman, 2011; Tjosvold \& Wisse, 2009).

For several reasons, this approach is particularly appealing with reference to GVCs. For one, interdependencies are germane to the nature of GVCs whose co-specialized nature entails that value creation by each constituency determines the ability of others to create value. This implies that there are high levels of reciprocal interdependencies among participants which shape the nature of the relationships among them (Gereffi et al., 2005). The appeal of an interdependence relationships lies in that it derives its transformative power from the very conditions that cause distortions in value distribution - that is, power and interdependence asymmetries (Medema, 2007), turning the causes of the distortions into the force for correcting them.

Moreover, participants' contribution to value creation by the GVC depends on their ability to appropriate value because resources available for participants to invest in value creation are generated via value appropriation (Chatain \& Zemsky, 2011; Lepak et al., 2007; Pitelis, 2009). In such value-creation systems, interests of individual actors cannot be fully separated from each other (Deutsch, 1973), undermining the effectiveness of uni-directional sources of power whereby powerful actors impose their will on less powerful ones (Dahl, 1957; Emerson, 1962). Interdependence relationships offer adequate basis for the understanding of these dynamics because they enable one to conceptualize relationships that connect participants to each other simultaneously in shared interest in maximizing joint value creation and in competition for respective shares of this value (Tjosvold \& Wu, 2009).

In addition, the interdependence logic is in tune with the ubiquity of relational governance in GVCs (Gereffi et al., 2005; Coe et al., 2008; Dicken et al., 2001). This governance mechanism resides outside the domain of formal authority and undermines sources of power that derive their impetus from such authority (Mayer \& Gereffi, 2010). The power of interdependence, which originates in reciprocity and mutual interests in the pursuit of exchange relationships, is consistent with these non-market voluntary relational governance mechanisms and overcomes limitations of concepts of power that are based on control and domination (Schrank, 2005). This is ever more so as these relational dynamics take place across local jurisdictions that operate in parallel to each other with no sovereign with hegemonic authority and power to control them (Overdevest \& Zeitlin, 2014, 2018; Sabel \& Zeitlin, 2010).

Lastly, the interdependence logic is less sensitive to the erosion effect of crossing borders that is inherent in the way GVCs function. As constituencies become foreign when they cross borders, their power is transformed and at time entirely dissipates, undermining the value of sources of power that are defined by borders (McGrath, 2018; Mezzadra \& Neilson, 2013). These GVC attributes make the interdependence logic a powerful mechanism for changing behavior, and offer compelling logic for conceptualizing distributional outcomes in GVCs. In the following section, I outline the variety of ways by which interdependence relationships empower GVC participants to amend behavior and channel it towards social causes. 


\section{THE POWER OF INTERDEPENDENCIES AS A MEANS TOWARDS BALANCED VALUE DISTRIBUTION}

The premise of interdependence theory is that goals' overlap and dependence on actions of others for their achievement create interdependence relationships among otherwise independent constituencies (Coleman et al., 2010). The greater the need for resources of others as a condition for the attainment of own goals, the stronger the interdependence relationships. GVCs are prime example of such situations. The desire to benefit from specialization has led to fragmentation of the production among multiple participants, each specializing in a single part of the production and dependent on others for both inputs into its own production as well as for market for its output (Gereffi, 2018). The sources of interdependence vary considerably in their substance and nature, but they share a common feature in that one's goal cannot be accomplished without some provisions of others (Johnson \& Johnson, 2005; Kelley et al., 2003). For instance, Apple is dependent upon Foxconn for the manufacturing of its electronic components; Bangladesh is dependent on cotton-growing countries for the production of textiles. Neither of these can accomplish their own production goals without these respective inputs. In turns out that Foxconn is dependent on Apple for its ability to put its manufacturing skills to effective use and cottongrowing countries need Bangladesh as a market for their cotton.

The strength of interdependencies varies across constituencies to relationships because some have more alternative options to achieve their goals than others (Coleman et al., 2010; Emerson, 1962; Tjosvold \& Wisse, 2009). Size variations determine the availability of one's own resources as possible alternatives for reliance on others (Dindial, Clegg, $\&$ Voss, 2020). Resource-rich entities may possess some of the resources internally, making them less dependent on others, or else have access to alternative sources that offer similar benefits (Johnson \& Johnson, 2005). Greater specialization and assets specificity to relationships that have little productive use outside of them reduce alternative sources and increase interdependencies (Williamson, 1996). These differences create interdependence asymmetries among members to the relationships (Coleman et al., 2010). For instance, Zara employs its own resources to manufacture internally about half of the apparel it sells, reducing its dependence on apparel manufacturers. H\&M employs about
2000 manufacturers around the world, decreasing its dependence on individual manufacturers and enabling it to switch production among them.

Asymmetries give less-dependent actors the power to amend the behavior of the more dependent ones. GVCs offer multiple examples of the way by which less-dependent participants, including lead firms, countries, and civil society, employ their power to amend the behavior of more dependent participants in directions they deem appropriate. Dependent actors, whose dependency originates in the narrow range of alternatives they have for given relationships, are likely to accept the demand of powerful members and amend their behavior accordingly. Less-dependent members have incentives to employ their power to modify others' behavior because their own goal achievement depends on the behavior of others (Magee \& Galinsky, 2008; Tjosvold \& Wisse, 2009). The pressure of global apparel brands on their manufacturers to improve governance standards in their factories in order for them to avoid reputational damage on this ground is a case in point (Alamgir \& Banerjee, 2018; Donaghey \& Reinecke, 2018). These variations define the options and constraints that constituencies can impose on others, the mechanisms they have to amend each other behavior, and the strength of their transforming power (Lammers \& Galinsky, 2009).

Interdependence relationships are inherent in the nature of GVCs, whose fragmented, co-specialized character implies that participants' ability to produce output is entirely dependent upon inputs received by others (Gereffi, 2018). The multiplicity of the participants involved in GVCs, their varying positions and roles, and their diverse sources of power create a variety of complex interdependence relationships (Levy, 2008).

Thus, in low-skilled, labor-intensive industries, size, skills, and financial power variations among lead firms, their manufacturers and labor create vast interdependence asymmetries (Dindial et al., 2020; Gereffi et al., 2005). Lead firms' global reach and mobility enable switching manufacturers and countries at relatively low cost, offering them more alternative options than those available to the manufacturers, and reducing their interdependence on them. Lead firms in these industries engage with thousands of suppliers whose skills are often undifferentiated, and at time develop capabilities that are specific to lead firms' needs. Ikea's relationships with its South-East Asian manufacturers suggest an example of such relationships. 
Capability upgrade and greater differentiation of these manufacturers increased interdependence asymmetries due to their specificity to Ikea's needs (Ivarsson \& Alvstam, 2011). Elsewhere, interdependence relationships might be characterized by a lower level of asymmetry, such as the relationships between China's SIAM and GM, and at time no asymmetries, for which the relationships between Apple and Foxconn suggest an example (Dindial et al., 2020. Apple is Foxconn's dominant client and Foxconn handles the majority of Apple's production, and both firms have found it difficult to diversify their business relationships (Chan, Pun, \& Selden, 2013).

Interdependence asymmetries also prevail at the macro level (Baldwin, 2012; Newman \& Posner, 2011). Political scientists have long recognized that globalization entails that countries' political and economic prosperities are inextricably tied together in complex interdependence relationships (Keohane \& Nye, 1973, 1987; Wagner, 1988). These interdependencies serve as a source of power employed by governments to modify the political discourse in other countries, and achieve various political goals. In the context of GVCs, the fragmented nature of the production and the separation of the production and consumption that characterizes GVCs gives less-dependent countries leverage over more dependent ones. The power of these interdependencies and the balance between the participating entities to the relationships depends on their own resources and the alternative they have. For instance, in low-skill, low-cost GVCs, there are often multiple sources of supply whereas the consumption is concentrated in a small number of countries. This creates large interdependence asymmetries between producing and consuming countries, giving the latter power to demand change in return for market access. The power that originates in these interdependences can be employed in a variety of ways, for the greater good of those holding the power, keeping blind eyes to injustice and human-rights violations, or else to demand social change and governance standards (Farrell \& Newman, 2019).

GVC production-related interdependencies are nested within a global political system in which multiple international organizations (IGOs) with varying mandates and sources of power create additional layers of interdependence relationships (Abbott \& Snidal, 2000, 2010; Gereffi, 2019; Levy, 2008; Rodrik, 2020; Standing, 2008). They serve as a form of supranational governance mechanism that mediates between national and international norms to improve governance standards in GVCs. IGOs are a natural constituency to oversee global phenomena like GSCs but by their nature lack regulatory power. Their power originates in the endorsement of their signatory members. The latter in return are dependent upon IGOs for their credibility and legitimacy in the political milieu, creating interdependence relationships that originate in soft power (Nyu, 2004). IGOs can affect social behavior in GVCs by directly demanding decision-makers to change their behavior in line with preferred outcomes, and indirectly by mobilizing other governments to exert pressure and pose a credibility threat for non-compliance to act in line with their preference (Barnett \& Finnemore, 2004).

The formal institutional structure that surrounds GVCs operates within a broad set of informal, voluntary associations such as NGOs, human-rights organizations, and other multi-stakeholder pressure groups. These create a form of private global governance that has exhibited remarkable power to bring about behavioral change (Cabral et al., 2019; Chambers \& Kopstein, 2006), leading commentators to refer to it as a 'dictatorship of virtue' (Hayden, 2002). Although deprived of any formal entitlement, civil society has become the de facto 'legitimating authority' whose moral demands serve as forceful potency in enforcing social standards and shaping GVC distributional outcomes (Palazzo \& Scherer, 2006). This power has been utilized in relation to all GVC constituencies, including producing entities, national governments, and international organizations. The diffused nature of civil society and its amorphic form lowers its dependency on others but legitimation dynamics also operate the other way around, albeit to a lower degree. Figure 1 summarizes the interdependence relationships among the multiple constituencies involved in GVCs, and shows the multiple layers in which interdependencies take place.

The power of the interdependence relationships summarized in Figure 1 manifests via a variety of mechanisms. Interdependencies among lead firms, manufacturers, and labor originate in market-based relationships and are dictated by market forces of supply and demand. These economically driven interdependencies could be extended to the domain of social behavior. The introduction of codes of conduct by lead firms across GVCs, which represent privately imposed standards that define 
Figure 1 Interdependence relationships in global value chains (arrows specify the interdependence relationships).

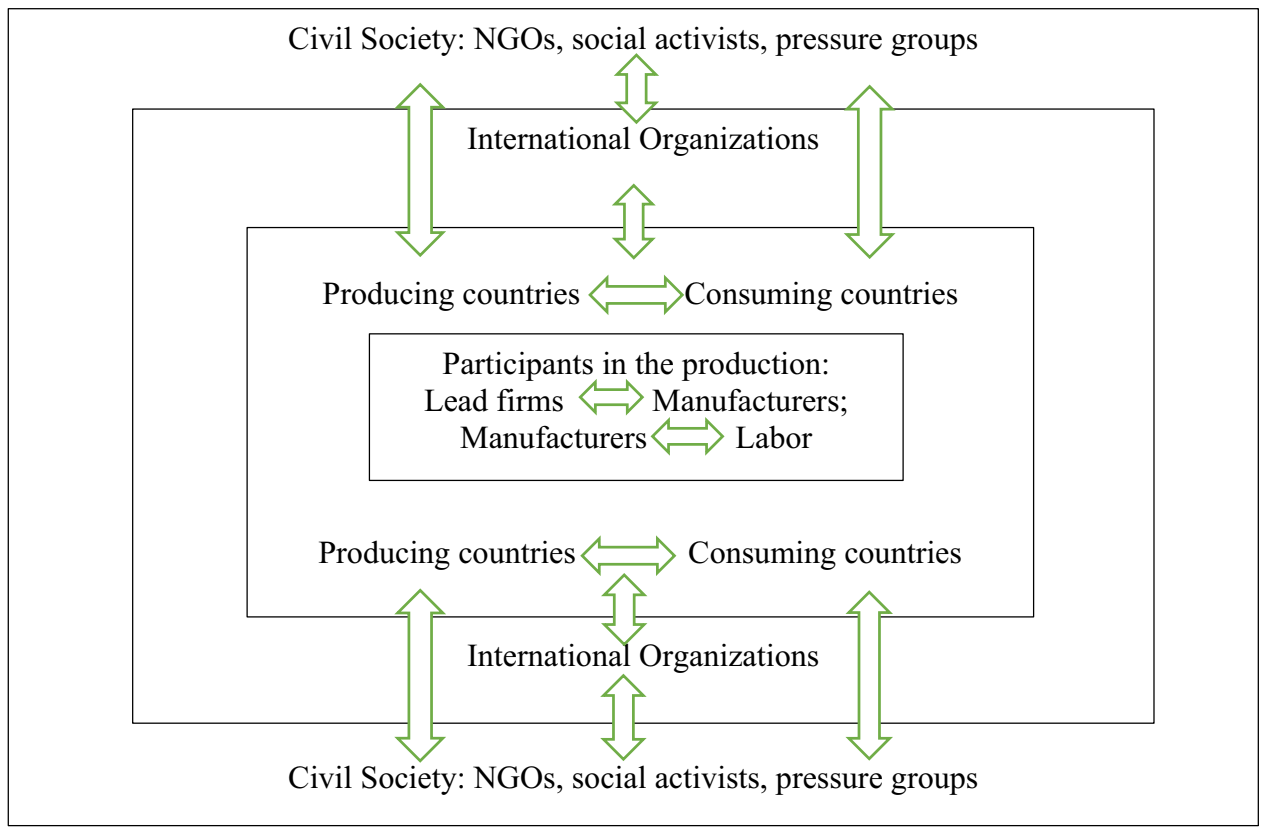

the terms of governance, derive their enforcement power from the dependency of the manufacturers on lead firms for access to markets (Hamilton, Senauer, \& Petrovic, 2011). Lacking statutory authority to inspect or penalize other firms, the regulatory power of lead firms comes instead from their behavior as customers. As gatekeepers to large consumer markets, they can reward compliant suppliers with more business and punish violators by excluding them from their supply chains (Amengual, Distelhorst, \& Tobin, 2020). Lead firms thus evoke market forces to alter manufacturers' incentives towards socially desired behavior and create economic costs for non-compliance (Bartley, 2018; Distelhorst et al., 2015; Distelhorst \& Locke, 2018). Indeed, research shows that just being connected to global networks, via either trade or outsourcing linkages, improves labor conditions in GVCs (Berik \& Rodgers, 2010), speaking to the power of lead firms to bring change.

Interdependencies are also apparent between firms and governments (Tjosvold, Peng, \& Chen, 2008). Governments' control over access to markets and resources that firms need give them the power to demand change. Requests by governments of producing countries for pay raises to manufacturers for output sold, or demand to assume responsibility for improvement of labor conditions in factories suggest examples of such power. In parallel, firms' mobility and ability to flexibly relocate their activities offer them power in the relationships with governments seeking to attract investment to their countries (Henisz \& Zelner, 2005).

Governments also have a variety of mechanisms to amend each other's behavior, both bilaterally, by evoking political and economic interdependencies, and multilaterally, by activating other governments and multi-governmental bodies to impose collective pressures. By employing these mechanisms, governments create political and economic costs for non-compliance and could amend the political discourse towards social change (Barnett \& Duvall, 2005; Newman \& Posner, 2011; Wagner, 1988). Schrank (2009) demonstrates how the US government conditioned preferential market access on improvement of industrial relations in the Caribbean Basin, at the time the source of half the apparel imported into the US. Policymakers in the Caribbean Basin changed their labor laws into compliance with international standards and enforced them when they signed the Dominican Republic-Central American Free Trade Agreement with the US.

IGOs' power to advance their social agenda manifests in the form of soft laws whose ratification by member states gives them power and authority. IGOs utilize this power to pose a threat to countries' credibility and legitimacy within the global political milieu (Abbott \& Snidal, 2000, 2010). They have demonstrated the ability to impose their normative framework to orchestrate coordinated actions by public, private, and social stakeholders 
and leverage their convening power to promote social change (Postuma \& Rossi, 2017). For instance, the ILO was instrumental in the establishment of Bangladesh's ACCORD and extending it to building safe and sustainable working conditions in factories after the Rana Plaza disaster (Donaghey \& Reinecke, 2018).

Civil society exploits publicity and threat of legitimacy damage as its prominent mechanism, using media venues for questioning and criticizing behavior its members deem inadequate (Hayden, 2002; Kaldor, Anheier, \& Glasius, 2003; Sangeeta, 2003). As social justice and inequality assumed premier position in determining economic, political, and social legitimacy of firms and countries, this form of soft power has manifested across GVCs. Voluntary adaptation of codes of conduct by lead firms illustrate the transformative power of such pressures (Locke, 2013). Legitimacy damage has become a powerful mechanism to amend national and regional political agendas as well (Anholt, 2006; Soule \& Olzak, 2004). The introduction of minimum wage legislation and its enforcement across countries were often in response to such pressures. These have also served to enact private certification schemes and legal requirements towards the construction of sustainable transnational governance regimes (Overdevest \& Zeitlin, 2014, 2018). Jepersen et al. (2014) show that negative publicity initiated by NGOs was the most decisive factor that led to the adoption of public and private standards in food GVCs in Asia.

Table 1 summarizes the interdependence relationships in GVCs and presents their determinants and power to bring about change. It illustrates the variety of economic and political costs that can be created via interdependencies among GVC participants, and shows their power to alter incentives and change behavior. In the following section, I outline the contextual conditions that determine the effectiveness of the power derived from interdependence relationships to amend distributional distortions across different GVCs. I suggest that interdependence relationships afford participants the power to change behavior but society determines whether they utilize it towards maximization of broad social welfare or otherwise.

\section{CHANNELING THE TRANSFORMING POWER OF INTERDEPENDENCE TOWARDS BALANCED VALUE DISTRIBUTION: THE IMPACT OF SOCIETAL CONTEXT}

Interdependence theory posits that interdependence relationships and their outcomes are subject to societal approval, in which legitimation processes define their nature and boundaries. Hence, the range of acceptable interdependence relationships and the scope of behavior associated with them reflect societal norms and vary across societal contexts (Coleman et al., 2011; Kelly et al., 2003). Societal norms also delineate the boundaries for the utilization of the power that originates in interdependence relationships (Malinoski, 2012; Oyserman, 2006; Tjosvold, Sun, \& Wan, 2005). Interdependence theory further suggests that societal claims for approval are particularly prevalent in relation to distributional justice, and they manifest most powerfully when interdependence relationships are strong and asymmetries are substantial, as

Table 1 Interdependence relationships in GVCs

\begin{tabular}{|c|c|c|}
\hline Relationships & $\begin{array}{l}\text { Determinants of interdependence } \\
\text { asymmetries and strength }\end{array}$ & Mechanisms to amend behavior \\
\hline Labor-manufacturers & Skills, differentiation & Market-based employer-employee relationships \\
\hline $\begin{array}{l}\text { Manufacturers--lead } \\
\text { firms }\end{array}$ & $\begin{array}{l}\text { Skills, differentiation, financial prowess, } \\
\text { market power, geographic scope, GVC } \\
\text { position }\end{array}$ & Market-based buyer-supplier relationships \\
\hline $\begin{array}{l}\text { Manufacturers/lead } \\
\text { firms-countries }\end{array}$ & $\begin{array}{l}\text { Monopolistic power over resources and } \\
\text { markets within jurisdictions }\end{array}$ & Access to resources; terms of use \\
\hline $\begin{array}{l}\text { Producing countries- } \\
\text { consuming countries }\end{array}$ & Market access; consumption behavior & $\begin{array}{l}\text { Trade relationships; political relationships - sanctions, soft } \\
\text { power (bilaterally, multilaterally); consumers' boycotts and } \\
\text { purchasing behavior }\end{array}$ \\
\hline $\begin{array}{l}\text { Producing/consuming } \\
\text { countries-IGOs }\end{array}$ & Members' endorsement; soft power & $\begin{array}{l}\text { Mobilize members to execute agenda; legitimacy/credibility in } \\
\text { global political milieu }\end{array}$ \\
\hline $\begin{array}{l}\text { All participating } \\
\text { firms/countries-civil } \\
\text { society }\end{array}$ & Broad societal legitimacy & Publicity via media venues; 'court of public opinion' \\
\hline
\end{tabular}


they often are in GVCs (Caney, 2005; Deutsch, 1985).

Societal context is thus likely to be a powerful force that shapes the effectiveness of the interdependence logic as a mechanism for advancing social welfare in GVCs. Specifically, it determines which constituencies are perceived as legitimate actors in affecting value distribution and are awarded the power to instill change. Studies show vast variations across countries in legitimating actors such as private and foreign firms, IGOs, and civil society to exploit the power of interdependence relationships towards the accomplishment of societal goals (Barry, 2001; Caschili et al., 2015; GjØlberg, 2009). As well, societal context determines constituencies' inclination to employ their power and channel private gains towards broad societal gains (Janmaat, 2013; Schmidt-Catran, 2016). Societies vary in their collective views of egalitarian distribution among society members, and these variations are closely reflected in government policies and other institutional arrangements (Greckhamer, 2011; Malinoski, 2012; Oyserman, 2006). Further, context determines constituencies' ability to activate the interdependence power to bring about social change, including the economic and financial means to do so, and the rights to express their voice without threat of negative consequences (Chambers \& Kopstein, 2006). Freedom of expression varies a great deal across countries, jeopardizing the underlying mechanisms that enable constituencies to express their view of social injustice and exercise their power to amend it (Brechenmacher, 2017). Absent these characteristics, interdependence relationships are unlikely to provide a viable mechanism for correcting for distributional distortions in GVCs.

GVCs create complex context for the manifestation of interdependence power. Driven by the desire to exploit cross-country differences in resources and skills (Gereffi, 2018), they are typically scattered across diverse societal settings, and are subject to multiple and often conflicting views of interdependencies and the exploitation of their power. They create incompatible demands for transnational regulatory integration in the face of starkly different needs of the countries involved in GVCs, and continuous struggle to strike a balance between conflicting logics (Bartley, 2018; Bruszt \& McDermott, 2014; Greenwood, Diaz \& Li, 2011; Levy, 2008).

In Figure 2, I present a parsimonious classification of the contextual combinations of varying constellations of GVCs distinguished by the power of the interdependence logic to amend distribution distortions. I refer to producing and consuming countries as the locus of the negotiation for value capture and the arena in which the power of the interdependence logic as a mechanism for social change is being contested. ${ }^{2}$ The transacting constituencies, namely lead firms, their suppliers and employees, and the respective national governments involved, are associated with the producing and consuming countries by way of citizenship, legal place of incorporation, and jurisdiction. Although global by their very nature, the power of IGOs and civil society is determined by the extent to which these countries affiliate themselves with these institutions and enable their power within their jurisdictions. Societal perception of the interdependence logic and its power in the producing and consuming countries thus determine its effectiveness in correcting for distributional distortions.

Simplifying assumptions that underlie the framework presented in Fig. 2 should be borne in mind when discussing its implications. The split into high- and low-interdependence countries hide
Figure 2 Context, the power of interdependence relationship, and value distribution in GVC.

\begin{tabular}{|c|c|c|c|}
\hline & \multicolumn{2}{|c|}{ Consuming Country } \\
\hline & & Low & High \\
\hline \multirow{2}{*}{ 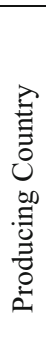 } & ב & $\begin{array}{c}1 \\
\text { Distorted value distribution } \\
\text { (Interdependence relationships ineffective } \\
\text { in administering value distribution) }\end{array}$ & $\begin{array}{l}\mathbf{2} \\
\text { Distributional outcomes determined via } \\
\text { interdependence asymmetries between } \\
\text { conflicting logics of producing entities }\end{array}$ \\
\hline & 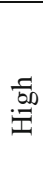 & $\begin{array}{c}\mathbf{3} \\
\text { Distributional outcomes determined via } \\
\text { interdependence asymmetries between } \\
\text { conflicting logics of consuming and } \\
\text { producing entities }\end{array}$ & $\begin{array}{c}\mathbf{4} \\
\text { Balance value distribution } \\
\text { (Driven by interdependence relationships) }\end{array}$ \\
\hline
\end{tabular}


nuances of this power as a continuum with the full range of degrees between high and low interdependence. Further, a single GVC may bring together multiple consuming and producing countries with different interdependence scores, blurring the distinction between high- and low-interdependence countries.

Below I discuss the likely effectiveness of the power of interdependence relationships to instill socially desired value distribution in the different GVCs represented in Figure 2. I illustrate these dynamics by a range of examples drawn from the apparel industry. This industrial focus enables me to observe the impact of the interdependence logic in isolation from that of industrial characteristics. As one of the most global and diverse GVCs, the apparel GVC is particularly appealing for this study. The global apparel industry was worth more than \$1.4 trillion in 2019, 14\% higher than in 2018 (McKinsey, 2020). According to World Trade Organization trade statistics, in 2018, growth of global apparel trade accounted for more than $10 \%$ of the annual growth in world export value, the highest share by any single industry. Importantly for my interest here, this vast and dynamic economic activity takes place in globally spread production networks that bring together a highly diverse set of players, with different sources of power and means of value creation. These participants are guided by different moral and normative stances towards societal equality and justice (Laudel, 2010; Powell, 2014), making the negotiations that govern value distribution highly contentious (Rodriguez-Garavito, 2005; Schrank, 2004; Tokatli, 2013). These features offer a rich context for observation of the relationships of interest.

\section{Cell 1: Interdependence Power Ineffective in Administering Value Distribution - Distorted Value Distribution}

Cell 1 represents GVCs in which both the producing and consuming countries are low-interdependence countries that do not endorse egalitarian distribution and prohibit actions towards social upgrading. Such a societal context is likely to undermine the inclination and ability of GVC constituencies to exercise the power of interdependencies to correct for distributional distortions, turning these distortions into the status quo.

The apparel industry in Ethiopia suggests an example. Ethiopia's wages for garment workers are the world's lowest, about a quarter of the lowest elsewhere, according to the International Labour
Organization's (ILO) wage statistics. Ethiopia has not ratified the ILO human-rights and minimum wage agreements, and has no minimum wage legislation. Foreign investment has been at the center of Ethiopia's economic growth model and low wages were perceived as central to the achievement of this goal (Oqubay, 2019). Although Ethiopia endorsed the ILO's Freedom of Association Convention already in 1963, well-functioning labor unions are rare, and ineffective in expressing workers' voices and improving their negotiating power vis-à-vis employers. With strong control over the Internet and social media, Ethiopian authorities have hindered societal pressure for change. In 2019, Internet shutdowns in Ethiopia were more frequent and lasted longer than in any other African country but Algeria (Karombo, 2020). Ethiopia ranks at the bottom of the FHI 360's Civil Society Index, an indicator of the capacity of civil society to bring about change, among all SubSaharan-African countries but Angola and Burundi. Although the second most populous country in Africa and the 12th in the world, the number of NGOs in the country is below the emerging market average, as well as Ethiopia's participation in IGOs.

Nor has foreign participation amended distribution distortions. The ownership and management of most textile and apparel manufacturing facilities in Ethiopia have demonstrated little, if any, concern for governance practices and social welfare in their factories. Almost all the textile and apparel manufacturers in Ethiopia originate in China, India, Pakistan, and Turkey, countries ranked low on multiple indicators of the prevalence of interdependence, such as freedom of speech, egalitarianism, and openness, below even many other emerging markets. Only three manufacturers involve Western ownership, and the small scale of outsourcing by other Western brands has undermined their power to instill change (Mihretu \& Llobet, 2017). Attempts by global activists and human-rights advocates to put pressure for change have had no consequences in the face of tightly held power by Ethiopia's government (Barrett \& Baumann-Pauly, 2019).

Ethiopia suggests an example of a situation in which interdependence relationships are an ineffective mechanism to improve distributional outcomes. In its desire to attract foreign investment and boost global competitiveness, Ethiopia's government has forfeited social goals. This example demonstrates the critical role that local forces play in enabling the power of interdependence to 
manifest itself and shows the inability of lead firms, IGOs, and civil society to instill change in the face of opposing government (Brustz \& McDermott, 2014; Distelhorst et al., 2015). Studies have demonstrated similar outcomes elsewhere. Lead firms in Bangladesh have achieved minimal improvement of labor conditions and distributional outcomes in the face of non-cooperative and at times opposing governments (Bair, Anner, \& Blasi, 2020; Siddiqui \& Uddin, 2016). The ILO Better Work Program failed to improve social conditions in Indonesia's garment industry for similar reasons (Amengual \& Chirot, 2016).

\section{Cell 2: Distributional Outcomes Negotiated Between Conflicting Interdependence Logics of Producing Entities}

Cells 2 and 3 represent GVCs situated across societal settings with mixed, and at times, conflicting views, of the interdependence logics and its power. Typically, in such situations, the logic of the less-dependent participant, whose less dependency affords him or her more power in the relationships, prevails, and at the extreme, may gain full dominance over the other logic (Ashraf, Ahmadsimab, \& Pinkse, 2017; Casciaro \& Piskorski, 2005; Greenwood et al., 2011). In GVCs, however, interdependence asymmetries are usually less decisive and involve elements of mutual dependence, challenging the reconciliation of conflicting logics and the creation of a balanced integration among them (Bartley, 2018; Bruszt \& McDermott, 2014). Cells 2 and 3 present varying forms of the co-existence of conflicting logics.

Cell 2 describes GVCs established by global brands, most typically originating in Western countries, seeking to take advantage of low-cost production in some of the world's poorest countries to sell low-cost products predominantly in Western markets. For instance, $84 \%$ of H\&M sales in the 2010s were generated in these markets (although the share of emerging markets has been growing rapidly) whereas its production is outsourced to nearly 2000 independent apparel manufacturers predominantly in emerging markets. The gap between the producing and consuming countries is such GVCs creates tension between conflicting logics and shapes varying distributional outcomes.

The apparel industries in Bangladesh and Cambodia offer an example. These countries are similar in terms of their level of economic development and industrial structure, but social welfare in their apparel industries varies considerably (Berik \&
Rodgers, 2010). Laborers in Cambodia's apparel industry are among the highest paid employees in the country's manufacturing industries, and their wages have been rising continuously over decades (Thul, 2018). In comparison, wages of Bangladeshi workers have deteriorated in real terms over the years, falling far short of the increase in labor productivity registered during this period (Uramoto \& Nachum, 2018). Further, in comparison to three 2012/13 fatal incidences in apparel factories in Bangladesh with a combined toll of 1252 deaths, Cambodia registered a single fatal incident with a death toll of two people (Stephenson, 2013).

A number of societal conditions offer an explanation for these differences. For one, fewer than 5\% of Bangladesh's 4 million garment employees are unionized, representing some of the weakest labor union conditions in Asia (Kucera, 2004; Siddiqui \& Uddin, 2016). Bangladesh's factory owners enjoy considerable political clout, holding about $10 \%$ of the Bangladesh Parliament's 350 seats and having strong ties with government officials. These factors enable them to tilt policy in directions that serve their goals and keep low wage levels and lax safety standards in their factories (Alamgir \& Banerjee, 2018; Chalmers, 2013). Even the 2013 Rana Plaza tragedy that placed Bangladesh at the center of the global debate on labor conditions and pay in GVCs has not brought about noticeable change (Bair, Anner, \& Blasi, 2020).

In contrast, unionization rates among Cambodia's 300,000 apparel employees are among the highest of any major apparel-producing country, giving Cambodian labor power to exercise their voice on a range of issues ranging from failure to raise wages to labor safety (Stephenson, 2013). Cambodia's government has demonstrated a strong commitment to the improvement of labor conditions and closely supervised their implementation. Further, in contrast to the predominantly local ownership of Bangladeshi factories, Cambodia's textile and garment factories have been foreignowned by firms from Taiwan, Singapore, Thailand, and Malaysia throughout their entire history (Kolben, 2004). These foreign owners have been pivotal in securing labor pay and safety conditions in their production facilities.

Governments of consuming countries have played a critical role in improving distributional distortions in Cambodia by utilizing the power of interdependence. In 1999, the US signed a bilateral trade deal with Cambodia that conditioned market access of apparel export to the US upon 
improvements in labor standards. In contrast to strong resistance for change in Bangladesh, there was broad support for the program of Cambodia's Garment Manufacturers Association, policymakers, employer organizations, and trade unions (Berik \& Rodgers, 2010; Polaski, 2006). Cambodia's taxation level is indicative of social endorsement of egalitarian distribution that is absent in Bangladesh. When adjusted to size (Cambodia population is about a tenth of Bangladesh's), Cambodia has more than four times the number of NGOs than Bangladesh and its membership of IGOs is almost eight times that of Bangladesh, speaking for societal legitimation of these influences on local social affairs.

Variations in interdependence asymmetries in the respective GVCs suggest another reason for varying distributional outcomes in the two countries. Bangladesh is the world's second-largest apparel exporter and has a production capacity to support production volumes on a scale and scope that few apparel exporters can match (Yunus \& Yamagata, 2012). This advantage has given the Bangladesh government leverage in negotiations with other GVC constituencies that Cambodia does not have. Even in the aftermath of the Rana Plaza tragedy that exposed the extent of distortions in Bangladeshi apparel factories, only a few global brands threatened to divest if the situation did not improve, and none actually left (Barrett, BaumannPauly, \& Gu, 2018). Bangladesh's comparative advantage appears to diminish interdependence asymmetries, giving its own societal logic greater weight in the negotiation for value distribution. Cambodia's relative weakness, in contrast, introduces high interdependence asymmetries, enabling the societal logic of the high-interdependence producing entities to prevail and dictate outcomes.

The example of Cambodia demonstrates how the empowerment of labor via unions, supported by both local government policy and US policy, operated to bring about social change. Absent these forces, as the example of Bangladesh shows, lead firms were unable to instill change (Bair et al., 2020). This conclusion is consistent with studies that point to the complementarity between transnational forces and local institutions as key for social change (Bartley, 2011; Coslovsky \& Locke, 2013; Locke, 2013).

\section{Cell 3: Distributional Outcomes Negotiated Between Conflicting Interdependence Logics of Consuming and Producing Entities}

Cell-3 GVCs represent a collision of conflicting societal logics that blend low-interdependence consuming countries with those of high-interdependence producers. These GVCs are the outcome of growing demand in low-interdependence countries, typically developing and emerging countries, for products produced in the West (Deloitte, 2018; McKinsey, 2017). Brands' country of origin represents the sense of exclusivity and prestige that increasingly wealthy consumers in these countries seek to express via their consumption behavior (Han, Nunes, \& Dreze, 2010; Hennings et al., 2012; Pino et al., 2019). These turn the location of the production in high-interdependence countries into a competitive imperative (Takatli, 2012). In contrast to cell-2 GVCs whereby the power of interdependence manifests via production relationships, in cell-3 GVCs it takes place via brands and products, at time even without any physical presence (Batrtley, Soener, \& Gershenson, 2019; Bhattacharya \& Sen, 2003; Bhattacharya et al., 2011).

Alas, attempts by high-interdependence producers to reflect on values and norms via branding and positioning in low-interdependence as a means for social change have often backfired and caused dire consequences (Achabou \& Dekhili, 2013; Torelli, Monga, \& Kaikati, 2012). An early example of such outcomes is the Italian fashion company Benetton, at the time Europe's largest clothing group and one of the world's largest. Perhaps more than any other fashion company, Benetton transformed its brands and products into vehicles for the expression of social values and norms and employed them to address social causes such as race, inequality, and justice. Not only did these attempts fail to bring about desired social change in low-interdependence countries, they raised suspicion regarding their actual motivations, and caused significant damage to Benetton's business. South Africa's boycott of Benetton and its campaigns, notably those that advocated racial equality, is a case in point (Gee, Pinson, \& Tibrewala, 1996). South Africa has the world's highest Gini coefficient, a measure of inequality, double that of Italy and other European countries.

More typically, fashion firms have relinquished their power to bring about social change and have opted for congruity with local value systems in lowinterdependence countries. The endorsement of women's traditional status in low-interdependence 
societies via fashion branding, in conflict to gender equality views typical of high-interdependence countries, illustrates this approach (Heinberg et al., 2020; Hung, Li, \& Belk, 2007). Benetton itself has abandoned the social contents of its branding in favor of conciliatory positioning as its commitment to social causes came to be seen as a major reason for its decline (Wells \& Danskin, 2014). The high dependency of apparel companies on low-interdependence countries as the sources of increasingly larger shares of their business and anticipated future growth (Deloitte, 2018; McKinsey, 2017) has given consuming countries power to resist change. The desire of low-interdependence consumers to associate themselves with Western brands has not extended to social values, in contrast to consumers in high-interdependence countries (Sharma, 2011).

Cell-3 GVCs demonstrate the manifestation of the interdependence logic in the relationships between firms and their consumers. They suggest limits to the ability to convey social messages and settle conflicting societal logics via branding, and offer indications regarding the boundaries of interdependence relationships as a force for change. Research in this area demonstrated the limits of transnational efforts to bring about social change in the absence of supportive government authorities, in agreement with cell-1 GVCs (Amanguel \& Chirto, 2016; Bartley, 2018; Locke, 2013). Cell-3 GVCs illustrate similar dynamics in relation to consumers and show the limits of transnational solutions in the absence of consumers' empowerment.

Cell-2 and -3 GVCs demonstrate two types of conflicts between the constituencies involved, as they manifest in production (cell-2) and consumption (cell-3). In both cases, transnational forces originating in high-interdependence countries are confronted by resistance from local constituencies in low-interdependence settings. In both cases, the outcomes are determined by interdependence asymmetries between the parties in which the logic of the less-dependent actor prevails and dictates the terms of the relationships (Ashraf et al., 2017; Casciaro \& Piskorski, 2005).

\section{Cell 4: Balanced Value Distribution (Driven by Interdependence Relationships)}

Cell 4 describes GVCs whereby both the production and the consumption take place in high-interdependence countries. The participating countries share similar views regarding social equality and endorse the employment of interdependence power to amend distributional distortions. Evidence of distorted distribution also abounds in these societies (Piketty, 2014), but consistencies between consuming and producing countries enable the interdependence power to manifest itself and amend these distortions to a large extent.

In the apparel industry, cell-4 GVCs are typically those constructed by global fashion luxury brands. ${ }^{3}$ The imperatives of the 'Made In' effect and quality control have favored the concentration of the production in high-interdependence countries (albeit with some outsourcing to lower-cost countries), and low-price elasticity liberated these companies from the cost pressure that has pushed other apparel firms to move the production to lowcost countries (Tokatli, 2012). High-interdependence countries are also major markets for luxury fashion, and the center of fashion trends and innovation (Godart, 2012).

With a few exceptions, luxury fashion brands were not traditionally associated with concerns about social causes such as human rights and wellness, even while those trends have been sweeping through elsewhere. The association of luxury fashion with glamour, exclusivity, and celebrity was perceived as incompatible with social justice, and engagements with such causes even posed a threat to brand image and reputation (Achabou \& Dekhili, 2013; Joy et al., 2012). Indeed, evidence of distorted practices throughout the entire supply chain abounds, from the production through the runaway to the high-end stores (Feng \& Negai, 2020).

This, however, has changed considerably in recent years, driven by consumers' pressure. Luxury fashion major consumers - celebrity and other high-value consumers - became vocal advocates of societal causes, and demanded the introduction of sustainability agenda in fashion as well. These pressures have been backed by the investment community as it started to incorporate sustainability performance in financial evaluation (Winston, 2016), and created strong incentives for the pursuit of social causes and changing the trade-off between social activity and economic gains that had prevailed in earlier decades.

Commitment to social causes has thus become a competitive imperative for luxury fashion brands, and came to be seen as a major source of differentiation and a fundamental part of the overall brands' image (Battachatarya \& Sen, 2003; Battachatrya et al., 2011; Torelli et al., 2012). 'Shop For A Cause' and charity-based campaigns by luxury 
fashion brands have proliferated, as these firms sought to embrace societal causes in their own supply chains as well as 'beyond the runaway' (Karaosman et al., 2020). The US-based Ninety Percent fashion company has regarded its social mission so central to its image that it adopted it as its name. The company donates $90 \%$ of its profits to charities of its customers' choosing (Lewittes, 2018). The LVMH Group and Kering's WeCareForModels.com project, which offers expert advice for fashion models from nutritionists and coaches, encapsulates the dedication of these companies to promoting the working conditions and well-being of their models. Wages of sale associates of high-end luxury brands, traditionally low-paid jobs, were also under scrutiny and higher wages became part of the social agenda, according to Fahionista reports. Employment statistics of the US Bureau of Labor show compensation levels of these apparel workers on par with the median wage in the US.

Cell-4 GVCs show the power of consumers, and more broadly society in large, as a force for social change. Social justice and belief in human rights and equality are deeply embedded in the societal fabrics of the countries involved in cell-4 GVCs, predominantly Western European and North American countries that are the home of the world's largest luxury fashion brands and the largest markets for their output (Godart, 2012). Distributional policies via taxation, minimum wage legislation, etc., are among the world's most egalitarian, speaking for societal belief in social justice. Freedom of speech and plurality of views are also fundamental principles in these societies (Barry, 2001). Increasing concerns about social justice in recent decades, combined with digital technology and social media that democratized freedom of expression to an extent never seen before brought these forces to the fore (Bachattarya et al., 2011; Winston, 2016). ${ }^{4}$ The contrast with cell-3 GVC vividly illustrates the varying impact of consumers' power in different societal contexts. Interdependence asymmetries tilt the trade-off between social behavior and economic gains into different directions, leading to the dominance of different societal logics in these respective GVCs.

Taken together, the discussion above illustrates the variety of ways by which the interdependence logic manifest as a force for social change in GVCs of different types, and shows how these variations lead to different distributional outcomes. Where the societal characteristics that unleash the interdependence power are absent, e.g., in cell-1 and cell-3 GVCs, value distortion prevails, whereas where it is unleashed by societal conditions that endorse its power, the interdependence logic is a powerful force for change, as cell-4 and to some cell-2 GVCs show. These varying outcomes enable to draw the boundaries of the interdependence logic, and show its limits as a mechanism for social change.

The discussion above also enables one to identify the constituencies concerned in activating or arresting the interdependence logic and the type of relationships that matters for the distributional outcomes in different GVCs, whether among producing entities as in cell-1 and cell-2 GVCs (Bartley, 2018), or else between consumers and producers (cell-3 and cell-4 GVCs), via brands and products, at time even without direct engagement (Bachattarya et al., 2011, Bartley et al., 2019). Variations in interdependence asymmetries among these constituencies shape different tradeoffs between social behavior and economic gains and result in the dominance of one societal logic over the other under varying circumstances, explaining the varying distributional outcomes across different GVCs (Ashraf et al., 2017; Greenwood et al., 2011). In the following section, I discuss the ways by which governments influence these dynamics.

\section{GOVERNMENT POLICY AND THE POWER OF INTERDEPENDENCE RELATIONSHIPS AS A FORCE FOR VALUE DISTRIBUTION IN GVCS}

\section{Passive Government Policy}

By design or default, governments may relinquish their power to advance social welfare in GVCs and delegate authority for distributional issues to private entities (Bartley, 2018; Mayer \& Phillips, 2017). Such passive governments are common in cell-4 GVCs, typically reflecting neoliberal ideas about 'the power of the market to fix the market' (Budish, Lee, \& Shim, 2019), and solve social problems without government intervention. As I have shown above, in such circumstances, the power of interdependence relationships becomes the force for change, and evokes a variety of non-regulatory mechanisms that create a market for social justice, modifying behavior in directions that correct for distributional distortions by dynamics that are internal to the supply chain (Strang \& Braithwaite, 2001).

The discussion above has also shown that while this approach has often been effective in improving 
distributional outcomes in cell-4 GVCs that operate in various high-interdependence countries, its success in low-interdependence countries has been mixed at best. Absent societal pressure to channel the power of interdependencies towards advancing social justice, passive governments enable private actors to utilize their power to appropriate disproportional shares of values themselves, as the example of Bangladesh factory owners demonstrates. Lead firms may put price pressure on manufacturers, which is often passed on to workers in the form of low wages and poor working conditions (Human Rights Watch, 2019; Locke, 2013; Locke \& Samel, 2018). They were also found to award work to factories run in full compliance with their codes of conducts, whereas those that violated these codes continue to receive work (Bartley, 2011). In a study of the garment industry in Indonesia, Amengual and Chirot (2016) show that efforts by the ILO Better Work Program to improve distributional outcomes are also conditioned upon the presence of active governments that empower global constituencies to enforce compliance. Amengual et al. (2020) show that rigid contracting relationships prevented the buyer from using order allocation to reward improvement and inflexible commercial relationships constrain buyers' ability to provide incentives to promote labor compliance. Nor is the effectiveness of civil society as a force for social change always self-evident in the absence of government. As increasing shares of GVC value are generated by lead firms originating in low interdependence countries and sold in such countries (cell-3 GVCs), civil society may not be a force for just value distribution and social welfare (Coslovsky, 2014).

\section{Facilitative Government Policy}

Governments of both producing and consuming countries may play a facilitative role by steering the direction of actions by GVC constituencies towards socially desired outcomes. In this capacity, governments create the conditions that enable GVC constituencies to unleash the interdependence power towards balanced value distribution (Bartley, 2011; Distelhorst et al., 2015). For instance, governments may introduce policies that reinforce actions by private actors towards improvement of labor standards. Studies suggest that in many cases, such facilitating actions by governments might be the key predictor of lead firms' ability to impose codes of conduct and ensure manufacturers' compliance (Amengual, 2010; Coslovskey, 2014;
Coslovsky \& Locke, 2013; Locke, 2013; Locke, Rissing, \& Pal, 2013; Zeitlin, 2011).

Another venue via which producing government policies can facilitate the power of interdependence relationships is by reducing interdependence asymmetries in GVCs relationships, for instance, by supporting labor unions. Such endorsements facilitate the emergence of labor unions and enable labor to exercise collective agency and bargain for enhanced pay and working conditions, as the example of Cambodia suggests as well as studies elsewhere (Hastings, 2019; Stringer et al., 2014). Yet another facilitative role by governments is by supporting the development of local capabilities. As manufacturers move up the value chain, their differentiation options increase, strengthening their negotiating power and enabling them to appropriate greater value via GVC participation (Görg \& Seric, 2013).

Consuming countries' policies have also played a facilitating role, both unilaterally and in collaboration with others, by activating the power of interdependence to bring about change. The US has frequently evoked its power by using preferential access clauses to demand change and force producing countries' governments to introduce favorable social policies. The suspension of Bangladesh's preferential tariffs following the Rana Plaza tragedy until workers' rights improve suggests an example. This action led to a raise of the minimum wage ahead of the requirement of Bangladesh's labor law (Greenhouse, 2013). The US exercised such pressure in the Caribbean Basin as well, to analogous effects (Schrank, 2009). Similar attempts have also been made at the regional level, championed by the EU, in the form of labor provisions in regional trade agreements (Coslovsky, 2014; O'Brien et al., 2000; Polaski, 2004). The success of the ILO Better Work Programme in mobilizing national and global constituencies to improve labor conditions demonstrates the facilitative power of IGOs.

\section{Active Government Policy}

Governments may assume an active role in distributing GVC value. Rather than creating the conditions for actions by other constituencies, which governments do as facilitators, active governments embrace themselves actions designed to distribute value in socially desired manner. In this capacity, governments employ legislative, monetary, and distributive power to activate interdependence dynamics (Davis, et al., 2018). In their legislative capacity, governments can set legally mandatory terms to dictate the conditions under 
which GVCs operate. They may also offer monetary rewards in return to improvement of working conditions, and employ minimum wage legislation and taxation to distribute value (Mayer \& Phillips, 2017). The so-called 'Nordic Model' of social responsibility (GjØlberg, 2010) illustrates how the interdependence logic has been institutionalized by active governments that have been actively imposing it via their policies. The introduction of legally binding clauses for social standards in trade agreements with strict enforcement provisions whereby violations entail economic sanction or withdrawal altogether, represents attempts by consuming countries to evoke the independence logic by their own actions (Campling et al., 2016; Haworth, Hughes \& Wilkinson, 2005).

A noteworthy difference between governments in facilitative or active capacities relate to the tools via which their power manifest. As facilitators, governments may impose soft power to bring about change whereas in their active capacity governments often employ legislative power to introduce policies that would lead to desired outcomes. These differences entail that active government policy is exercised predominantly at the national level, as regional associations and IGOs lack the enforcement power needed for such policies.

As supply chains became global in their entire value-creating activities, however, the ability of both national and regional governments to effectively regulate social conduct, even those domiciled within their jurisdictions, has diminished and at time dissipated entirely (World Bank, 2020). Increasingly fragmented and footloose GVCs have exposed the limits of national and regional regulatory stance to amend their conduct and revealed their legitimacy deficits as they aspire to regulate global affairs (Mayer \& Gereffi, 2010; Zhou \& Cuyvers, 2011). Studies demonstrate the failure of the EU to regulate labor standards in apparel factories in Moldova (Smith et al., 2018) and Morocco (Barrientos, Gereffi, \& Rossi, 2011), pointing at the mismatch between the EU goals and the global structure of GVCs. The failure of continuous attempts to regulate social standards in GVCs on a multilateral level via the WTO (Campling et al., 2016) have further undermined the effectiveness of active government policy.

\section{Inhibitive Government Policy}

Governments have the ability to do away with the power of the interdependence logic altogether and undermine its effectiveness as a mechanism for administering value distribution. They employ this power when amendments of distributional distortions are inconsistent with their political and/or economic goals, as the example of Ethiopia suggests. Through formal policy constraints and sanctions, governments define the scope of actions that receive political accreditation, and approve the private constituencies that can embrace them. They also have the power to draw the boundaries of the desired societal outcomes.

Governments can inhibit labor association, weakening labor's ability to strengthen their power vis-àvis their employers, and arrest efforts by lead firms to improve governance practices in their supply chains. Bartley's (2018) study of labor practices in Indonesia and China shows that local repression limits what global standards could accomplish. Governments that shy away from collaborative relationships via international institutions and challenge their efforts to change domestic regulatory stance undermine yet another venue via which the power of interdependence relationships can bring about social change. Government policies may also arrest efforts by civil society to activate the interdependence logic as a mechanism for change.

Table 2 presents a summary of the varying roles that governments assume in determining the effectiveness of interdependence relationships in GVCs. It suggests that, at least in the apparel industry that was my focus here (see more on this below), governments' facilitative role leads to the most desired distributional outcomes. In this role, whereby active governments assume the distributive capacity themselves or else undermine the social conditions that enable it, governments create the conditions that enable GVC constituencies to unleash the power of interdependencies towards just value distribution. The effectiveness of this policy across GVC types further accentuates its appeal. Passive policy stance, in which governments relinquish social welfare to private participants, is also effective in amending distributional distortions, but its limited scope to high-interdependence settings undermines its power in contexts in highest need of amendments. As the discussion above also suggests, other policy roles arrest the interdependence logic or else undermine its effectiveness, to the detrimental of distribution justice. Attention thus shifts to the policy actions that would unleash the power of interdependencies to amend distributional distortions rather than to tackling the task itself. This discussion suggests that 
Table 2 Government policy and the effectiveness of the interdependence logic as a mechanism for value distribution (in italics policies likely to lead to improved distributional outcomes)

\begin{tabular}{|c|c|c|c|c|}
\hline \multirow{2}{*}{$\begin{array}{l}\text { Policy } \\
\text { role: }\end{array}$} & \multicolumn{2}{|c|}{ Unilaterally: } & \multirow{2}{*}{$\begin{array}{l}\text { Multilaterally: Trade } \\
\text { agreements, IGOs }\end{array}$} & \multirow{2}{*}{$\begin{array}{l}\text { Implications for value } \\
\text { distribution }\end{array}$} \\
\hline & Producing countries & $\begin{array}{l}\text { Consuming } \\
\text { countries }\end{array}$ & & \\
\hline
\end{tabular}

Passive Responsibility for value distribution outsourced to private GVC constituencies

Facilitative Enable activation

interdependence power by

other participants:

1. Supportive legislation to lead

firms' initiatives;

2. Reduce interdependence

asymmetries: Capability

development of local

manufacturers;

3. Reduce interdependence asymmetries: Unionization and labor burgeoning power

Active Replaces interdependence logic in administering value distribution:

1. Legislative role (minimum wage);

2. Distributive role (taxes);

3. Monetary role (tax benefits)

Inhibitive

Prevents exploitation of

interdependence power by

private GVC constituencies:

Prohibiting restrictions on lead

firms' initiatives, labor unions,

civil society freedom of speech

\author{
Market access \\ conditional upon \\ improvement of \\ distributional \\ outcome: Bilaterally \\ Market access conditional \\ upon improvement of \\ distributional outcome: \\ Multilaterally; Activating \\ members' actions
}

Legally binding social standards included in national trade policy

Unable/not
interested in
activating the
interdependence
logic

Unable/not interested in logic
High-interdependence countries: Value distribution administered via interdependence relationships;

Low-interdependence countries: Distorted value distribution

Value distribution administered via interdependence relationships
The absence of enforcement power undermines active policy role

Prohibited by producing country governments from exercising their power to activate the interdependence logic
Effectiveness of interdependence logic undermined by limitations of national and regional policy to administer globally scattered GVCs; Distorted value distribution Interdependence logic ineffective; Distorted value distribution the interdependence logic does not replace governments. Rather, its effectiveness appears to depend on government policies and might be undermined without them.

\section{DISCUSSION AND POSSIBLE EXTENSIONS}

In this paper, I proposed a new mechanism for addressing the lingering challenge of value distribution in GVCs based on the power of interdependence relationships to reward socially desired behavior and create costs for non-compliance. By creating markets for social justice that derive their transformative power from within, the interdependence logic turns GVCs into their own de facto 'regulators' with the power to self-correct for distributional distortions (Budish et al., 2019). This logic is particularly appropriate for a production system in which multiple constituencies scattered around the world operate in tandem without a hegemon with the power to set up global rules (Schrank \& Whitford, 2011; Zeitlin, 2011). I have demonstrated multiple paths for bringing about social change, by incorporating social values into branding or else via mobilization of key stakeholder groups, including governmental and non-governmental ones. I have also shown that notwithstanding its appeal, the transformative power of the interdependence logic depends on the presence of societal conditions that legitimate its use and channel it towards the improvement of social welfare. Societal context determines the extent to 
which interdependence relationships can amend social distortions. This contextual variation is associated with diverse role of government policy, as it determines the effectiveness of the interdependence logic as a force for change. These conclusions are consistent with studies that have demonstrated the critical role of domestic empowerment in the success of transnational solutions to improve value distribution in GVCs (Bartley, 2011; Brutlz \& McDermott, 2014; Coslovsky \& Locke, 2013; Distelhorst et al., 2015; Locke, 2013). The employment of the interdependence logic enables me to offer a novel perspective to the mechanisms through which the complementarity between transnational solutions and local institutions emerge.

Moreover, I extended the scope of discussions of value distribution to GVCs that have received limited attention by research thus far. Echoing the predominant nature of GVCs during the last decades (Milberg \& Winkler, 2013; Powell, 2014), extant research has focused almost entirely on North-South GVCs (cell-2, Fig. 2). Recent developments, including growing South-South production relationships (cell-1 GVCs), changing balance between consuming and producing countries (cell-3 GVCs) and between labor and capital (cell4 GVCs) have given rise to GVCs of different types. Anti-globalization sentiments, automation and robotics, and most recently the global COVID-19 pandemic, have caused lead firms to shift production to their home countries in the developed world, transforming cell-2 GVCs into cell 4. As I have shown in this article, these GVCs raise different challenges for value distribution and embody varying means for the employment of the interdependence logic as a force for change. Their incorporation in the theoretical framework I developed enabled me to extend theory and policy discussions in important ways and draw attention to relationships that have gone unnoticed by extant research.

The paper opens up a large area for future research to further articulate the dynamics of the interdependence logic and draw its boundaries as a force for change. GVCs vary considerably in their structure, the nature of the transactions, and participants' skill levels (Gereffi et al., 2005; Mahutga, 2014), and these differences affect interdependence asymmetries and the transformative power of interdependence relationships. For instance, while in the apparel industry there are considerable power asymmetries between manufacturers and lead firms, these are much smaller in the electronic industry (Locke \& Samel, 2018). Under such circumstances, lead firms have little, if any, leverage over manufacturers, questioning their effectiveness as agents of change (Locke et al., 2013). Pressure by civil society activists to amend distributional distortions likewise varies considerably across GVCs. Anti-sweetshop campaigns have been a major force for change in the apparel industry (Distelhorst \& Locke, 2018) but have seldom been activated in the mobile technology industry, in spite of considerable distributional distortions (Kraemer et al., 2011). The framework I developed here appears to be most effective in amending distributional distortions in certain types of GVCs, notably buyer-dominated GVCs (Gereffi et al., 2005; Mahutga, 2014). Its broader validity beyond these GVCs requires further scrutiny by future research.

Future research may also develop the understanding of the societal characteristics that affect the interdependence logic and its transformative power. Developing measures of this construct that would enable validate the framework I developed based on large-scale data would support this endeavor. There are no rigorous ways to measure the prevalence of the interdependence logic in a society, but some measures could offer indicative evidence. For instance, egalitarian view and the likelihood of societal pressure towards just social distribution are likely to be reflected in measures such as taxation policy, minimum wage legislation, and Gini coefficients. Similarly, freedom of expression can be proxy by measures of global freedom and Internet freedom. The number of NGOs in a country and the number of IGOs to which a country is a signatory are indicative of the power of these constituencies to instill change.

The study of GVCs situated in settings that do not support the interdependence logic as a force for change (cell 1 in Fig. 2) is also warranted in order to offer insights into possible solutions for distributional distortions under such circumstances. Future research may inquire broadly about alternative solutions in the absence of local inclination to enable the interdependence logic.

Another important task for future research is the study of new types of GVC participants, as they affect the dynamics of interdependence relationships and distributional outcomes. One such noteworthy participant is lead firms from lowinterdependence countries, often former contract manufacturers to global brands that upgraded along the value chain and started to sell their products under their own brand names around the world (Dindial et al., 2020; Tokatli, 2007). Although originating in low-interdependence 
countries, these firms often adopt most advanced governance practices in their GVCs, treating them as central to their efforts to establish themselves as credible and legitimate global brands and an imperative for their global aspiration. Turkey's Mavi jeans is a case in point. The company aims at much higher corporate responsibility and occupational practices than those required by Turkey's stock exchange where the firm is listed. Mavi had introduced voluntarily governance practices based on standards of high-interdependent countries, although more than $80 \%$ of its suppliers and nearly $90 \%$ of its labor force are based in Turkey (Avery \& Yucaoglu, 2019). This example shows that consuming-country standards can shape social practices in GVCs from far away also for less embedded entities (Bartley et al., 2019), and they are more influential than that of home countries.

Another change in GVC dynamics that warrants additional research attention is the rise of a new type of small fashion company that enters the market in large numbers in recent years, and is changing market dynamics and power relationships (McKinsey, 2020). The small scale of these firms is transforming a traditionally concentrated oligopolistic market of large global firms outsourcing from highly fragmented manufacturing industries into more equal balance of power between lead firms and their suppliers. It undermines lead firms' power to impose their governance practices on their suppliers, challenging a major venue for correction of distribution distortions (Locke, 2013). Civil society is also less attentive to the activities of such small firms and seldom targets their social standards (Geferri \& Mayer, 2010), further weakening the power of interdependence relationships as a mechanism for change.

\section{ACKNOWLEDGEMENTS}

I extend deep gratitude to Professor Rabellotti, one of the editors of this Special Issue, and to two anonymous referees for excellent guidance on the revision of the paper. The paper originates in a large-scale global project that was initiated and directed by Professor

\section{REFERENCES}

Abbott, K., \& Snidal, D. 2000. Hard and soft law in international governance. International Organization, 54(3): 421-456

Abbott, K. \& Snidal, D. 2010. International regulation without international government: Improving IO performance through orchestration. Review of International Organizations. 5: 315-344.
Yoshiteru Uramoto of Sofia University, Tokyo, with input from a team of researchers from around the world. The contributions of these constituencies are gratefully acknowledged, with special recognition extended to Professor Uramoto for his dedicated leadership and support.

\section{NOTES}

${ }^{1}$ Different terms have been employed in research in this area to describe the processes by which raw material, intermediaries, and semi-finished goods circulate among multiple participants scattered around the world and brought to market (see Kano, Tsang, \& Yeung, 2020 for review). A few predominant terms have emerged. These are global commodity chains (GCC) and its more recent evolution into the so-called global value chains (GVC) (Gereffi, 2018), often referred to as GCC/GVC. Another common term is global production networks (GPN) (Coe \& Yeung, 2015). These terms are underpinned by different theories and varying conceptualizations of the production systems. Although I blend elements of both approaches, I employ the term GVC because it is the more commonly employed in the literature.

${ }^{2}$ Implicit here is the assumption that the production and consumption are separated and take place in different countries, which is the typical case of GVCs. Value chains that do not correspond to this condition, commonly referred to as horizontal investment, are outside the scope of this paper.

${ }^{3}$ The introduction of robotics to apparel production has increased the prevalence of such GVCs beyond luxury fashion, but so far has been small in scale.

${ }^{4}$ Legislation by national and regional authorities, notably the EU, might have also played a role in legitimizing these societal concerns and supporting the conditions that enable their expression (Bartley, 2011; Campling et al., 20116). I will address this role in greater detail in the next section.

Achabou, A.M. \& Dekhili, S. 2013. Luxury and sustainable development: Is there a match? Journal of Business Research, 66(10): 1896-1903

Alamgir, F., \& Banerjee, S. B. 2018. Contested compliance regimes in global production networks: Insights from the Bangladesh garment industry. Human Relations, 72: 272-297. 
Amengual, M. 2010. Complementary labor regulation: The uncoordinated combination of state and private regulators in the Dominican Republic. World Development, 38: 405-414.

Amengual, M., \& Chirot, L. 2016. Reinforcing the state: Transnational and state labor regulation in Indonesia. ILR Review, 69(5): 1056-1080

Amengual, M., Distelhorst, G., \& Tobin, D. 2020. Global purchasing as labor regulation: The missing middle. ILR Review, 73(4): 817-840

Anholt, S. 2006. Public diplomacy and place branding: Where's the link? Place Brand and Public Diplomacy, 2: 271-275

Antràs, P. 2020. Conceptual aspects of global value chains. World Bank Economic Review

Ashraf, N., Ahmadsimab, A. \& Pinkse, J. 2017. From animosity to affinity: The interplay of competing logics and interdependence in cross-sector partnerships. Journal of Management Studies, 54: 793-822

Avery, J., \& Yucaoglu, G. 2019. Mavi: Fashioning a path to brand growth. Harvard Business School Case \#9-517-075

Bair, J. \& Werner M. 2011. Commodity chains and the uneven geographies of global capitalism: A disarticulations perspective. Environment and Planning A, 43: 988-997

Bair, J., Anner, M., \& Blasi, J. 2020. The political economy of private and public regulation in Post-Rana Plaza Bangladesh. ILR Review, 73(4): 969-994

Baldwin, R. E. 2012. Global supply chains: Why they emerged, why they matter, and where they are going. Centre for Economic Policy Research (CEPR), Discussion Paper No. DP9103

Baldwin, R. E. 2016. The great convergence: Information technology and the new globalization. Cambridge: Harvard University Press.

Bapuji, H., Ertug, G., \& Shaw, J.D. 2020. Organizations and societal economic inequality: A review and way forward. Academy of Management Annals, 14: 60-91

Barnett, M. \& Duvall, R. 2005. Power in international politics. International Organization, 59: 39-75.

Barnett, M., \& Finnemore, M. 2004. Rules for the world: International organizations in global politics. Cornell University Press, Ithaca

Barrett, P.M. \& Baumann-Pauly, D. 2019. Made in Ethiopia: Challenges in the Garment Industry's New Frontier. NYU Stern, Center for Business and Human Rights

Barrett P., Baumann-Pauly D. and Gu A. 2018. Five years after rana plaza: The way forward. NYU Stern Center for Business and Human Rights

Barrientos, S., Gereffi, G., \& Rossi, A. 2011. Economic and social upgrading in global production networks: A new paradigm for a changing world. International Labor Review, 150(3-4): 319340

Barry, B. 2001. Culture and Equality: An Egalitarian Critique of Multiculturalism. Harvard University Press, Mass. Boston

Bartley, T. 2011. Transnational governance as the layering of rules: Intersections of public and private standards. Theoretical Inquiries in Law, 12: 517-542

Bartley, T., 2018. Rules without rights: Land, labor, and private authority in the global economy. Oxford: Oxford University Press

Bartley, T., Soener, M., \& Gershenson, C. 2019. Power at a distance: Organizational power across boundaries. Sociology Compass, 13(10): 1-14

Berik G. \& Rodgers YVMD. 2010. Options for enforcing labour standards: Lessons from Bangladesh and Cambodia. Journal of International Development, 22: 56-67

Bhattacharya, C.B., \& Sen, S. 2003. Consumer-company identification: A framework for understanding consumers' relationships with companies. Journal of Marketing, 67(2): 7688.

Bhattacharya, C.B., Sen, S., \& Korschun, FD. 2011. Leveraging corporate responsibility: The stakeholder route to maximizing business and social value. Cambridge University Press, Cambridge, UK.

Brechenmacher, S. 2017. Civil Society Under Assault: Repression and Responses in Russia, Egypt, and Ethiopia. Carnegie Endowment for International Peace.

Bruszt, L. \& McDermott G.A. (eds.) 2014. Levelling the playing field: Transnational regulatory integration and development. Oxford University Press: Oxford and New York.

Budish, E., Lee, R. S., \& Shim, J. J. 2019. Will the market fix the market? A theory of stock exchange competition and innovation. NBER w25855.

Cabral, S., Mahoney, J., McGahan, A. \& Potoski, M. (eds.) 2019. Value creation and value appropriation in the context of public and non-profit organizations. Strategic Management Journal, 40(4): Special Issue

Campling, L., Harrison, J., Richardson, B., \& Smith, A. 2016. Can labour provisions work beyond the border? Evaluating the effects of EU free trade agreements. International Labour Review, 155(3): 357-82

Caney, S. 2005. Global interdependence and distributive justice. Review of International Studies, 31(2): 389-399

Caschili, S., Medda, F.R. \& Wilson, A. 2015. An interdependent multi-layer model: Resilience of international networks. Networks and Spatial Economics, 15: 313-335

Casciaro, T., \& Piskorski, M. I. 2005. Power imbalance, mutual dependence, and constraint absorption: A closer look at resource dependence theory. Administrative Science Quarterly, 50(2): 167-199.

Chalmers J. 2013. Special Report: How textile kings weave a hold on Bangladesh. Reuters, May 2nd.

Chambers S., \& Kopstein J. 2006. Civil society and the state. In J.S. Dryzek et al. (eds.), The Oxford handbook of political theory. Oxford: Oxford University Press, pp. 363-381

Chan, J., Pun, N., \& Selden, M. 2013. The politics of global production: Apple, Foxconn and China's new working class. New Technology, Work and Employment, 28(2): 100-115.

Chatain, O. \& Zemsky, P. 2011. Value creation and value capture with frictions. Strategic Management Journal, 32(11): 1206-1231.

Coe, N.M., \& Yeung, H.W.C. 2015. Global production networks: Theorizing economic development in an interconnected world. Oxford: Oxford University Press.

Coe, N.M., \& Yeung, H.W.C. 2019. Global production networks: Mapping recent conceptual developments. Journal of Economic Geography, 19(4): 775-801

Coe, N.M., Dicken, P., \& Hess, M. 2008. Global production networks: Realizing the potential. Economic Geography, 8(3): 271-95.

Coleman, P.T. (ed.) 2011. Conflict, interdependence, and justice: The intellectual legacy of Morton Deutsch. New York: Springer. Coleman, P.T., Kugler, K., Mitchinson, A., Chung, C. \& Musallam, N. 2010. The view from above and below: The effects of power and interdependence asymmetries on conflict dynamics and outcomes in organizations. Negotiation and Conflict Management Research, 3: 283-311

Coleman, P. T., Vallacher, R. R. \& Nowak, A. 2011. Tackling the great debate. In P.T. Coleman (ed.), pp, 273-289.

Coslovsky, S. 2014. Flying under the radar? The state and the enforcement of labour laws in Brazil. Oxford Development Studies, 42(2): 190-216

Coslovsky, S., \& Locke, R. 2013. Parallel paths to enforcement: Private compliance, public regulation, and labor standards in the Brazilian sugar sector. Politics \& Society, 41: 497-526

Dahl, R.P. 1957. The concept of power. Behavioral Science, 2: 201-218.

Dallas, M.P., 2014. Cloth without a weaver: Power, emergence and institutions across global value chains. Economy and Society, 43(3): 315-345.

Dallas, M.P., Ponte, S., \& Sturgeon, T.J. 2019. Power in global value chains. Review of International Political Economy, 26(4): 666-694 
Davis, D., Kaplinsky, R., \& Morris, M. 2018. Rents, power and governance in global value chains. Journal of World-Systems Research, 24(1): 43-71.

Dedrick, J., Kraemer K.L., \& Linden, G. 2011. The distribution of value in the mobile phone supply chain. Telecommunications Policy, 35(6): 505-521

Deloitte. 2018. Global powers of luxury goods. Deloitte, Italy.

Deutsch, M. 1949. A theory of cooperation and competition. Human Relations, 21(2): 52-91.

Deutsch, M. 1973. The resolution of conflict. Yale University Press, New Haven: CT

Deutsch, M. 1985. Distributive justice: A social-psychological perspective. Yale University Press, New Haven.

Dicken, P., Kelly, P. F., Olds, K., \& Yeung, H. 2001. Chains and networks, territories and scales: Toward a relational framework for analyzing the global economy. Global Networks, 1(2): 1470-2266.

Dindial, M., Clegg, J., \& Voss, H. 2020. Between a rock and a hard place: A critique of economic upgrading in global value chains. Global Strategy Journal, 10(3): 473-495

Distelhorst, G., \& Locke, R.M. 2018. Does compliance pay? Firm-level trade and social institutions. American Journal of Political Science, 62(3): 695-711

Distelhorst, G., Locke, R.M., Pal, T., \& Samel H.M. 2015. Production goes global, compliance stays local: Private regulation in the global electronics industry. Regulation \& Governance, 9(3): 224-242.

Donaghey, J., \& Reinecke, J. 2018. When industrial democracy meets corporate social responsibility: A comparison of the Bangladesh Accord and Alliance as responses to the Rana Plaza disaster. British lournal of Industrial Relations, 56(1): 14-42.

Emerson, R. M. 1962. Power-dependence relations. American Sociological Review, 27: 31-41.

Farrell, H., \& Newman, A. 2019. Weaponized interdependence: How global economic networks shape state coercion. International Security, 44(1): 42-79.

Feng, P., \& Ngai, C.B. 2020. Doing more on the corporate sustainability front: A longitudinal analysis of CSR reporting of global fashion companies. Sustainability, 12: 2477

Gee, F., Pinson, C., \&, Tibrewala, V. 1996. United Colors of Benetton. INSEAD Case IN1261-PDF-ENG

Gereffi, G. 2018. Global value chains and development: Redefining the contours of 21 st century capitalism. Cambridge: Cambridge University Press.

Gereffi, G. 2019. Global value chains and international development policy: Bringing firms, networks and policy-engaged scholarship back in. Journal of International Business Policy, 2: 195-210

Gereffi, G., Humphrey, J., \& Sturgeon, T. 2005. The governance of global value chains. Review of International Political Economy, 12(1): 78-104

GjØlberg, M. 2009. The origin of corporate social responsibility: Global forces or national legacies? Socio-Economic Review, 7(4): 605-637

GjØlberg, M. 2010. Varieties of corporate social responsibility (CSR): CSR meets the "Nordic Model". Regulation \& Governance, 4(2): 203-229

Godart, F. 2012. Unveiling Fashion: Business, Culture and Identity in the most Glamorous Industry. Houndsmills: INSEAD Business Press, Palgrave McMillan.

Görg, H. \& Seric, A. 2013. With a little help from my friends: Supplying to multinationals, buying from multinationals, and domestic firm performance. UNIDO Development Policy, Statistics and Research Brunch

Grabs, J., \& Ponte S. 2019. The evolution of power in the global coffee value chain and production network. Journal of Economic Geography, 19: 803-828.

Greckhamer, T. 2011. Cross-cultural differences in compensation level and inequality across occupations: A set-theoretic analysis. Organization Studies, 32(1): 85-115
Greenhouse, S. 2013. Obama to suspend trade privileges with Bangladesh. New York Times, June 27th.

Greenwood, R., Diaz A.M. \& Li S.X. 2011. The multiplicity of institutional logics and the heterogeneity of organizational responses. Organization Science, 21(2): 521-539.

Hamilton, G.G., Senauer, B., \& Petrovic, M. (Eds.) 2011. The Market Makers: How Retailers are Reshaping the Global Economy. Oxford: Oxford University Press

Han, Y.J., Nunes, J.C., \& Drèze, X. 2010. Signaling status with luxury goods: The role of brand prominence. Journal of Marketing, 74(4): 15-30

Hastings, T. 2019. Leveraging Nordic links: South African labor's role in regulating labor standards in wine global production networks. Journal of Economic Geography, 19: 921-942

Haworth, N., Hughes, S., \& Wilkinson, R. 2005. The international labour standards regime: A case study in global regulation. Environment and Planning A, 37(11): 1939-1953

Hayden, R. 2002. Dictatorships of Virtue? States, NGOs, and the imposition of democratic values. Harvard International Review, 24(2): 56-61.

Heinberg, M., Katsikeas, C.S., Ozkaya, H.E., \& Taube, M. 2020. How nostalgic brand positioning shapes brand equity? Differences between emerging and developed markets. Journal of the Academy of Marketing Science, 48: 869-890

Henderson, J., Dicken, P., Hess, M., Coe, N., \& Yeung, H. W. C. 2002. Global production networks and the analysis of economic development. Review of International Political Economy, 9(3): 436-464

Henisz, W.J., \& Zelner, B.A. 2005. Legitimacy, interest group pressures and change in emergent institutions: The case of foreign investors and host country governments. Academy of Management Review, 30(2): 361-382

Hennings N., et al., 2012. What is the value of luxury? A crosscultural consumer perspective. Psychology \& Marketing Journal, 29(12): 1018-1034

Human Rights Watch. 2019. Paying for a bus ticket and expecting to fly: How apparel brand purchasing practices drive labor abuses. Human Rights Watch, IFO and ILO

Humphrey, J., \& Schmitz H. 2002. How does insertion in global value chains affect upgrading in industrial clusters? Regional Studies, 36(9): 1017-1027.

Hung, K. H., Li, S. Y., \& Belk, R. W. 2007. Glocal understandings: Female readers' perceptions of the new woman in Chinese advertising. Journal of International Business Studies, 38(6): 1034-1105

Ivarsson, I., \& Alvstam, C. G. 2011. Upgrading in global valuechains: A case study of technology-learning among IKEAsuppliers in China and Southeast Asia. Journal of Economic Geography, 11(4): 731-752

Janmaat, J. 2013. Subjective inequality: A review of international comparative studies on people's views about inequality. European Journal of Sociology, 54(3): 357-389

Jespersen, K.S., Kelling, I., Ponte, S., \& Kruijssen, F. 2014. What shapes food value chains? Lessons from aquaculture in Asia. Food Policy, 49(1): 228-240

Johnson, D.W., \& Johnson, R.T. 2005. New developments in social interdependence theory. Genetic, Social, and General Psychology Monographs, 131(4): 285-358.

Joy, A., Sherry, J.F., Venkatesh, A., Wang, J., \& Chan R. 2012. Fast fashion, sustainability, and the ethical appeal of luxury brands. Fashion Theory, 16(3): 273-296.

Kaldor, M., Anheier, H., \& Glasius, M. (eds.) 2003. Global civil society. Oxford: Oxford University Press.

Kano, L., Tsang, E. W. K. \& Yeung, H. W. 2020. Global value chains: A review of the multi-disciplinary literature. Journal of International Business Studies, 51: 577-622.

Kaplinsky, R. 2005. Globalization, poverty and inequality. Cambridge: Polity Press.

Karaosman, H., Perry, P., Brun, A. \& Morales-Alonso, G. 2020. Behind the runway: Extending sustainability in luxury fashion supply chains. Journal of Business Research, 117: 652-663 
Karombo, T. 2020. More African governments are quietly tightening rules and laws on social media. Quartz Africa, October 12

Kelley, H. H., Holmes, J. G., Kerr, N. L., Reis, H. T., Rusbult, C. E., \& Van Lange, P. A. M. 2003. An Atlas of interpersonal situations. New York, NY: Cambridge University Press.

Keohane, R. O., \& Nye, J. S. 1973. Power and interdependence. Survival, 15:4, 158-165

Keohane, R. O., \& Nye, J. S. 1987. Power and Interdependence revisited. International Organization, 41(4): 725-753.

Kolben, K. 2004. Trade, monitoring, and the ILO: Working to improve conditions in Cambodia's garment factories. Yale Human Rights and Development Law Journal, 7: 79-107.

Kraemer, K. L., Linden G. \& Dedrick J. 2011. Capturing value in global networks: Apple iPad and iPhone. Mimeo UC Irvin and Berkeley.

Kucera, D. 2004. Measuring trade union rights: A country-level indicator constructed from coding violations recorded in textual sources. ILO Policy Integration Department Working Paper No. 50.

Lammers, J., \& Galinsky A. D. 2009. The conceptualization of power and the nature of interdependency: The role of legitimacy and culture. In Tjosvold D. \& Wisse B. (eds.), pp. 67-99

Laudel, T. 2010. An attempt to determine the CSR potential of the international clothing business. Journal of Business Ethics, 96: 63-77.

Lepak, D.P., Smith, K.G., \& Taylor, M.S. 2007. Value creation and value capture: A multilevel perspective. Academy of Management Review, 32(1): 180-194.

Levy, D. 2008. Political contestation in global production networks. Academy of Management Review, 33(4): 943-963

Lewittes, E. 2018. 7 luxury brands that let you shop for a cause. Forbes, Aug. 19th

Locke, R.M. 2013. The promise and limits of private power: Promoting labor standards in a global economy. Cambridge, UK: Cambridge University Press.

Locke, R. M., \& Samel, H. 2018. Beyond the workplace: "Upstream" business practices and labor standards in the global electronics industry. Studies in Comparative International Development, 53: 1-24

Locke, R.M., Rissing, B.A. \& Pal, T. 2013. Complements or substitutes? British Journal of Industrial Relations, 51: 519-552

Magee, J. C., \& Galinsky, A. D. 2008. Social hierarchy: The selfreinforcing nature of power and status. Academy of Management Annals, 2: 351-398.

Mahutga, M. C. 2014. Global models of networked organization, the positional power of nations and economic development. Review of International Political Economy, 21(1): 157175

Malinoski, M. 2012. On culture and income inequality: Regression analysis of Hofstede's international cultural dimensions and the Gini Coefficient. Xavier Journal of Politics, III(1): 32-48

Mayer, F., \& Gereffi, G. 2010. Regulation and economic globalization: Prospects and limits of private governance. Business and Politics, 12(3): 1-25.

Mayer, F., \& Phillips, N. 2017. Outsourcing governance: States and the politics of a 'Global Value Chain World'. New Political Economy, 22(2): 134-152

McGrath, S. 2018. Dis/articulations and the interrogation of development in GPN research. Progress in Human Geography, 42: 509-528.

McKinsey. 2017. Chinese Luxury Consumers: The 1 Trillion Renminbi Opportunity. China Luxury Report, May

McKinsey. 2020. The State of Fashion 2020. McKinsey \& Company

Medema, S.G. 2007. The hesitant hand: Mill, Sidgwick, and the evolution of the theory of market failure. History of Political Economy, 39(3): 331-358.

Mezzadra, S., \& Neilson, B. 2013. Bordes as method. Duke and London: Duke University Press.
Mihretu, M. \& Llobet, G. 2017. Looking beyond the horizon: A case study of PVH's commitment to Hawassa's Industrial Park. June. Washington, DC: World Bank.

Milberg, W., \& Winkler, D. 2013. Outsourcing economics: global value chains in capitalist development. Cambridge: Cambridge University Press.

Miles, R.E., \& Snow, C.C. 2007. Organization theory and supply chain management: An evolving research perspective. Journal of Operations Management, 25(2): 459-463

Newman, A. L., \& Posner, E. 2011. International interdependence and regulatory power: Authority, mobility, and markets. European Journal of International Relations, 17(4): 589610.

Nye, J.S., 2004. Soft power: The means to success in world politics. New York: Public Affairs.

O'Brien, R., Goetz, A. M., Scholte, J. A., \& Williams, M. 2000. Contesting global governance: Multilateral economic institutions and global social movements. Cambridge: Cambridge University Press.

Oqubay, A. 2019. The Oxford handbook of the Ethiopian economy. Oxford and New-York: Oxford University Press.

Overdevest, C., \& Zeitlin, J. 2014. Assembling an experimentalist regime: Transnational governance interactions in the forest sector. Regulation \& Governance, 8: 22-48

Overdevest, C., \& Zeitlin, J. 2018. Experimentalism in transnational forest governance: Implementing European Union forest law enforcement, governance and trade (FLEGT) voluntary partnership agreements in Indonesia and Ghana. Regulation \& Governance, 12: 64-87

Oyserman, D. 2006. High power, low power, and equality: Culture beyond individualism and collectivism. Journal of Consumer Psychology, 16: 352-356

Palazzo, G. \& Scherer, A.G. 2006. Corporate legitimacy as deliberation: A communicative framework. Journal of Business Ethics, 66: 71-88

Piketty, T. 2014. Capital in the twenty-first century. Boston, MA: Harvard College.

Pino, G., Amatulli, C., Peluso, A. M., Nataraajan, R., \& Guido, G. 2019. Brand prominence and social status in luxury consumption: A comparison of emerging and mature markets. Journal of Retailing and Consumer Services, 46: 163-172

Pitelis, C. N. 2009. The co-evolution of organizational value capture, value creation and sustainable advantage. Organization Studies, 30(10): 1115-1139

Polaski, S. 2004. Protecting labor rights through trade agreements: An analytical guide. U.C. Davis Journal of International Law \& Policy, 10(13): 13-25.

Polaski, S. 2006. Combining global and local forces: The case of labor rights in Cambodia. World Development, 34(5): 919932.

Ponte, S., \& Gibbon, P. 2005. Quality standards, conventions and the governance of global value chains. Economy and Society, 34(1): 1-31

Postuma, A., \& Rossi, A. 2017. Coordinated governance in global value chains: Supranational dynamics and the role of the International Labour Organization. New Political Economy, 22(2): 186-202.

Powell, B. 2014. Out of poverty: Sweatshops in the global economy. Cambridge: Cambridge University Press.

Rodrige, J. P., Comtois, C., \& Slack B. (eds.) 2013. The geography of transport systems. London: Routledge.

Rodriguez-Garavito, C. A. 2005. Global governance and labor rights: Codes of conduct and anti-sweatshop struggles in global apparel factories in Mexico and Guatemala. Politics \& Society, 33: 203-233.

Rodrik, D. 2020. Putting global governance in its place. The World Bank Research Observer, 35(1): 1-18

Rossi, A. 2013. Does economic upgrading lead to social upgrading in global production networks? Evidence from Morocco. World Development, 46: 223-233 
Sabel, C. F., \& Zeitlin, J. (eds.). 2010. Experimentalist governance in the European Union: Towards a new architecture. Oxford: Oxford University Press

Sangeeta, K. 2003. NGOs and the new democracy. Harvard International Review, 25(1): 65-69.

Schmidt-Catran, A.W. 2016. Economic inequality and public demand for redistribution: Combining cross-sectional and longitudinal evidence. Socio-Economic Review, 14(1): 119-140

Schrank, A. 2004. Ready-to-wear development? Foreign investment, technology transfer, and learning by watching in the apparel trade. Social Forces, 83(1): 123-156

Schrank, A. 2005. Entrepreneurship, export diversification, and economic reform: The birth of a 'Developmental Community' in the Dominican Republic. Comparative Politics, 38: 43-62.

Schrank, A. 2009. Professionalization and probity in a patrimonial state: Labor inspectors in the Dominican Republic. Latin American Politics and Society 51(2): 91- 115

Schrank, A., \& Whitford, J. 2011. The anatomy of network failure. Sociological Theory, 29(3): 151-177.

Sharma, P. 2011. Country of origin effects in developed and emerging markets: Exploring the contrasting roles of materialism and value consciousness. Journal of International Business Studies, 42(2): 285-306.

Siddiqui, J., \& Uddin, S. 2016. Human rights disasters, corporate accountability and the state: Lessons learned from Rana Plaza. Accounting, Auditing \& Accountability Journal, 29(4): 679-704.

Smith, A., Barbu M., Campling L., Harrison J., Richardson B. 2018. Labor regimes, global production networks, and European Union trade policy: Labor standards and export production in the Moldovan clothing industry. Economic Geography, 94: $550-574$

Soule, S.A. \& Olzak, S. 2004. When do movements matter? The politics of contingency and the equal rights amendment. American Sociological Review, 69(4): 473-497.

Standing, G. 2008. The ILO: An agency for globalization. Development and Change, 3(3): 355-84

Stephenson, M. 2013. From sweatshop to smartshop: How AsiaPacific countries can use the lessons of the apparel industry in Bangladesh and Cambodia as a driver for inclusive growth. A report prepared for UNESCAP Trade and Investment division.

Strang, H. \& Braithwaite, J. (eds.) 2001. Restorative justice and civil society. Cambridge: Cambridge University Press.

Stringer, C., Simmons G., Coulston D., \& Whittaker D. H. 2014. Not in New Zealand's waters, surely? Linking labor issues to GPNs. Journal of Economic Geography, 14: 739-758.

Taglioni, D. \& Winkler, D. 2016. Making global value chains work for development. Washington, DC: World Bank

Thul, P. C. 2018. Cambodia hikes textile workers' minimum wage, falls short of union demands. Reuters, Oct. 5th.

Tjosvold, D., \& Wisse, B. (eds.) 2009. Power and interdependence in organizations. Cambridge: Cambridge University Press.

Tjosvold, D., \& Wu, P. 2009. Power in cooperation and competition: Understanding the positive and negative faces of power. In D. Tjosvold \& B. Wisse, (eds.), pp. 83-100

Tjosvold, D., Sun, H.F, \& Wan, P. 2005. An experimental examination of social contexts and the use of power in a Chinese sample. Journal of Social Psychology, 145(6): 645-661

Tjosvold, D., Peng, A.C., \& Chen, Y.F. 2008. Business and government interdependence in China: Cooperative goals to develop industries and the marketplace. Asia Pacific Journal of Management, 25: 225-249

Tokatli, N. 2007. Networks, firms and upgrading within the blue-jeans industry: Evidence from Turkey. Global Networks, 7: $51-68$
Tokatli, N. 2012. Old firms, new tricks and the quest for profits: Burberry's journey from success to failure and back to success again. Journal of Economic Geography, 12: 55-77

Tokatli, N. 2013. Toward a better understanding of the apparel industry: A critique of the upgrading literature. Journal of Economic Geography, 13(6): 993-1011

Torelli, C. J., Monga, A. B., \& Kaikati A. M. 2012. Doing poorly by doing good: Corporate social responsibility and brand concepts. Journal of Consumer Research, 38(5): 948-963

Uramoto, Y., \& Nachum, L. 2018. Corporate governance \& sustainability of the global value chain: Bangladesh ready-made garment industry. Unpublished report, Sophia University, Tokyo

Wagner, R. H. 1988. Economic interdependence, bargaining power, and political influence. International Organization, 42(3): 461-483.

Wells, J. R., \& Danskin, G. 2014. Benetton Group S.p.A. Harvard Business School Case 713513

Werner, M. 2019. Geographies of production I: Global production and uneven development. Progress in Human Geography, 43(5): 948-958

Williamson, O.E. 1996. The Mechanisms of Governance. Oxford: Oxford University Press

Winston, A. 2016. Luxury brands can no longer ignore sustainability. Harvard Business Review, Feb.

World Bank. 2020. Trading for development in the age of global value chains. Washington D.C.: World Bank.

Yunus, M., \& Yamagata, T. 2012. The apparel industry in Bangladesh. In Fukunishi (ed.), Dynamics of the Apparel Industry in Low-Income Countries: Experience of Asia and Africa. Chousakenkyu Houkokusho, IDT-JETRO.

Zeitlin, J. 2011. Pragmatic transnationalism: Governance across borders in the global economy. Socio-Economic Review, Presidential Address, SASE Annual Meeting 2010, Philadelphia, USA

Zhou, W., \& Cuyvers, L. 2011. Linking international trade and labor standards: The effectiveness of sanctions under the European Union's GSP. Journal of World Trade, 45(1): 63-85.

\section{ABOUT THE AUTHOR}

Lilach Nachum is Professor at Baruch College, City University of New York. Her current research interests include global supply chains and value creation in a global world, emerging market MNEs, and the relationship between firms, society, and governments as they shape the international strategies of firms. Her research in these areas and others has appeared in the Academy of Management Journal, Strategic Management Journal, and the Journal of International Business Studies, among others. At various periods, she has served on the editorial boards of the leading journals in strategy and international business, as a board member and a consulting editor. She is a Fellow of the Academy of International Business.

Publisher's Note Springer Nature remains neutral with regard to jurisdictional claims in published maps and institutional affiliations.

Accepted by Roberta Rabellotti, Guest Editor, February 23, 2021. This article has been with the authors for five revisions. 